\title{
Molecular Diagnosis of Subclinical African Trypanosoma vivax Infection and Association with Physiological Indices and Serum Metabolites in Extensively Managed Goats in the Tropics
}

\author{
Timothy M. Sanni' ${ }^{1}$, Gbolabo O. Onasanya ${ }^{1}$, Mufliat A. Adefenwa ${ }^{2,3}$, Abdulmojeed Yakubu ${ }^{3,4}$, \\ Christian O. N. Ikeobi $^{1}$, Olufunmilayo A. Adebambo ${ }^{1}$, Adewale O. Talabi ${ }^{5}$, \\ Michael O. Ozoje ${ }^{1}$, Mathew Wheto ${ }^{1}$, Michael I. Takeet ${ }^{3,6}$, Sunday O. Peters ${ }^{3,7}$, \\ Marcos De Donato ${ }^{3}$, Bolaji N. Thomas ${ }^{8}$, Ikhide G. Imumorin ${ }^{3 *}$ \\ ${ }^{1}$ Department of Animal Breeding and Genetics, Federal University of Agriculture, Abeokuta, Nigeria \\ ${ }^{2}$ Department of Cell Biology and Genetics, University of Lagos, Lagos, Nigeria \\ ${ }^{3}$ Department of Animal Science, Cornell University, Ithaca, USA \\ ${ }^{4}$ Department of Animal Science, Nasarawa State University, Shabu-Lafia Campus, Keffi, Nigeria \\ ${ }^{5}$ Department of Veterinary Medicine and Surgery, Federal University of Agriculture, Abeokuta, Nigeria \\ ${ }^{6}$ Department of Veterinary Microbiology and Parasitology, Federal University of Agriculture, Abeokuta, Nigeria \\ ${ }^{7}$ Department of Animal Science, Berry College, Mount Berry, USA \\ ${ }^{8}$ Department of Biomedical Sciences, Rochester Institute of Technology, Rochester, USA \\ Email: *igi2@cornell.edu
}

Received December 27, 2012; revised January 28, 2013; accepted February 27, 2013

\begin{abstract}
Trypanosomosis remains a major challenge to livestock production in much of tropical Sub-Saharan Africa, while diagnosis and treatment still depend on inefficient parasitological techniques. Endemic infections depend on animal reservoirs with subclinical parasitemia. We report molecular diagnosis of subclinical Trypanosoma vivax (T. vivax) infection using polymerase chain reaction (PCR) for the first time in Nigerian goats and associate parasite presence with gross physiological traits and serum metabolites in extensively managed Nigerian goats. PCR was used to amplify a 400 bp DNA fragment of the parasite genome in 205 goats across three geographical zones of the country. Results showed a high subclinical infection rate (SCIR) of 71.7\% in the total goats examined. Overall SCIRs of $71 \%, 75.9 \%$ and $55.6 \%$ were recorded in West African Dwarf, Red Sokoto and Sahel goats respectively, while geographical SCIRs were 71.2\% (Southwest), 75\% (Northwest) and 70\% (Northeast). T. vivax presence had significant $(\mathrm{P}<0.05)$ effect on respiratory rate and is associated with higher creatinine levels in sera. Logistic regression analyses with Hosmer-Lemeshow goodness-of-fit showed that respiratory rate is the most important predictive trait for the presence of $T$. vivax infection ( $\mathrm{P}<$ 0.05 ). Goats appear to be a viable reservoir for T. vivax infection of other livestock. Molecular diagnosis of subclinical trypanosomosis using PCR could be useful for large scale epidemiological studies, early diagnosis of subclinical infection and treatment of the disease in extensively managed tropical goats.
\end{abstract}

Keywords: Molecular Diagnosis; Trypanosoma vivax; Serum Metabolites; Physiological Indices; Nigeria; Goats

\section{Introduction}

Livestock productivity in Sub-Saharan Africa suffers from high prevalence of trypanosomosis with estimated annual losses due to the direct and indirect consequences of the disease running into billions of dollars with disproportionate adverse effects in rural areas [1-4]. The epidemiology of trypanosomosis and its impact on livestock production varies from one locality to another and

${ }^{*}$ Corresponding author. depends largely on the level of interaction between tsetse flies, domestic and game animals [5]. This protozoan disease is transmitted by the tsetse fly via the infection of animals and humans [6].

Small ruminants are renewable energy source for food, biological raw materials and play significant socioeconomic roles in the lives of rural dwellers in Africa. In Nigeria, trypanosomosis is of increasing clinical importance in small ruminants as the disease expands to previously tsetse free zones [7]. Several techniques have been 
developed for pathogenic trypanosome identification, characterization, typing, epidemiological data collection and diagnosis [8,9]. Molecular diagnosis includes the use of species-specific primers in single and nested PCR to amplify the internal transcribed spacer (ITS) regions of ribosomal DNA [10].

Epidemiological studies have shown high levels of mixed infections in tsetse flies feeding on naturally infected cattle and other livestock [11]. Despite much campaign towards trypanosome eradication, there is lack of research on the molecular screening of trypanosomes in Nigeria [7]. Better understanding of prevalence of subclinical infection will help with efforts to control the disease and the use of population-based screening of both animal and insect vectors. Therefore, the goal of this pioneer nationwide study was to establish the suitability of PCR-based assay in the effective diagnosis of subclinical Trypanosoma vivax infection and its association with physiological status and serum metabolites of extensively managed Nigerian goats in a tropical region.

\section{Materials and Methods}

\subsection{Animals and Sampling}

Two hundred and five goats (60 bucks and 145 does) representing 3 extant Nigerian breeds were sampled from across the country. The data set comprised 62 West African Dwarf (WAD), 116 Red Sokoto (RS) and 27 Sahel (SH) breeds distributed with 59 from Southwest (Ogun State), 56 from Northwest (Kano, Zaria, Sokoto and Kebbi States) and 90 from Northeast (Nassarawa, Jos, Bauchi, and Maiduguri States) zones of Nigeria respectively (Figure 1). The goats originated from different flocks and were reared under the traditional extensive system, where they grazed during the day on natural pasture containing forages such as stylo (Stylosanthes gracilis), leucaena (Leucaena leucocephala) and guinea grass (Panicum maximum), and scavenged on kitchen and household wastes whenever available. The animals' ages were assessed to be greater than 14 months by dentition (presence of 2 - 8 permanent incisors) as previously described [12].

\subsection{DNA Isolation and Polymerase Chain Reaction Screening}

Blood samples were collected by jugular venipuncture and genomic DNA were isolated using ZymoBead ${ }^{\mathrm{TM}} \mathrm{Ge}-$ nomic DNA kit (Zymo Research Corp., Irvine, CA, USA) following the manufacturer's instructions. The presence of Trypanosoma vivax (T. vivax) was determined by PCR using the $T$. vivax-specific primers ILO 1264/1265 forward 5'-CAGCTCGCCGAAGGCCACTT GGCTGGG3' and reverse 5'-TCGCTACCACAGTCG CAATCGTCGTCTCAAGG-3' to amplify a $400 \mathrm{bp}$ fragment of the parasite genome as described by Masake et al. [13] and adopted by Njiru et al. [14]. PCR amplifications were carried out in a Techne thermal cycler in a total reaction volume of $20 \mu \mathrm{L}$ containing $10-50 \mathrm{ng}$ DNA and 10 pmol of each primer in AccuPower ${ }^{\mathrm{TM}}$ PCR Premix (Bioneer Corporation, Alameda, CA, USA). The thermal cycling involved 35 cycles of initial denaturation at $95^{\circ} \mathrm{C}$ for 5 minutes, denaturation at $95^{\circ} \mathrm{C}$ for 30 seconds, annealing at $55^{\circ} \mathrm{C}$ for 120 seconds, extension at $72^{\circ} \mathrm{C}$ for 120 seconds, and final extension temperature at $72^{\circ} \mathrm{C}$ for 5 minutes. PCR products were separated in $1.5 \%$ agarose gel including ethidium bromide, and photographed under UV light. Confirmation by DNA sequencing of the amplified fragments was carried out using the same PCR primers with the Applied Biosystems Automated 3730 DNA Analyzer (Applied Biosystems, Carlsbad, CA, USA) using Big Dye Terminator chemistry and AmpliTaq-FS DNA Polymerase.

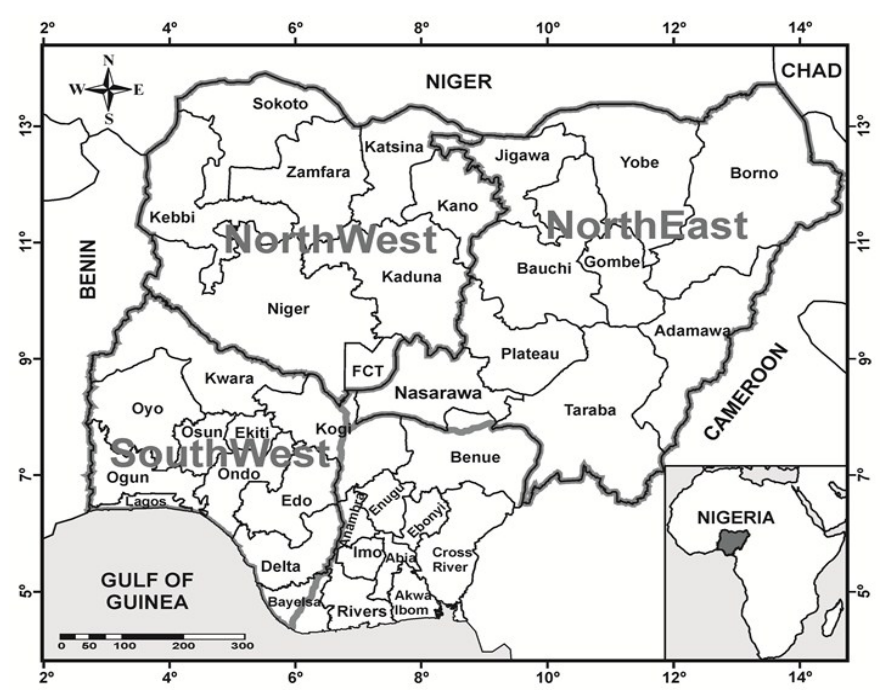

Figure 1. Nigerian map showing the geographical zones of sampling. 


\subsection{Physiological Indices and Serum Metabolites Measurement}

Digital thermometer was used to measure the body temperature via the fore limb armpit of the goats. Rectal temperature was measured with the digital thermometer placed about $2 \mathrm{~cm}$ in the rectum, while pulse rate was measured in beats per minute using a stethoscope placed on the $4^{\text {th }}$ half intercostal space. Respiratory rate was measured in breaths per minute by counting the number of flank movements per minute using a stop watch and stethoscope. The relationship between pulse rate and respiratory rate together with their normal average values was used to derive log transformed heat stress index (HSI) according to Olademeji et al. [15] as follows:

$\mathrm{H}=(\mathrm{AR} / \mathrm{AP}) \times(\mathrm{NP} / \mathrm{NR})$

where $\mathrm{H}=$ Heat stress index;

$\mathrm{AR}=$ Average respiratory rate value;

$\mathrm{AP}=$ Average pulse rate value;

$\mathrm{NP}=$ Normal pulse rate value;

$\mathrm{NR}=$ Normal respiratory rate value.

The following serum metabolites were measured according to Jain [16]: total blood glucose (TBG), total serum protein (TSP), blood urea nitrogen (BUN), alanine amino phosphatase (ALP), bilirubin (BIL), creatinine (CRT), triglycerides (TGS), serum albumin (ALB), total cholesterol (CHOL), high density lipoproteins (HDL), low density lipoproteins (LDL), globulin (GLB), calcium $\left(\mathrm{Ca}^{2+}\right)$, magnesium $\left(\mathrm{Mg}^{2+}\right)$, chloride $\left(\mathrm{Cl}^{-}\right)$, sodium $\left(\mathrm{Na}^{+}\right)$, potassium $\left(\mathrm{K}^{+}\right)$, phosphorus $\left(\mathrm{PO}_{4}^{2-}\right)$, serum glutamic oxaloacetic transaminase (SGOT) and serum glutamic pyruvic transaminase (SGPT).

\subsection{Statistical Analysis}

Based on presence of expected PCR products on gel bands, infection status were categorized as either positive or negative for $T$. vivax. The prevalence rates of $T$. vivax were assessed using frequency and percentages. The effects of $T$. vivax infection and breed of goats on physiological and serum metabolites were estimated using PROC GLM of SAS version 9.1 [17].

The linear model employed was:

$Y_{i j k}=\mu+A_{i}+B_{j}+e_{i j k}$

$Y_{i j k}=$ trait of interest;

$\mu=$ population mean;

$A_{i}=$ effect of $i^{\text {th }} T$. vivax infection status (infected, non-infected);

$B_{j}=$ effect of $j^{\text {th }}$ breed (WAD, RS, SH);

$e_{i j k}=$ random error associated with each record (assumed to be normally, independently and identically distributed with zero mean and constant variance).

Means were separated using the Duncan Multiple range test procedure of the same statistical package. Logistic regression analyses were carried out with HosmerLemeshow goodness-of-fit [18] to determine the physio- logical (heat tolerance) traits of utmost importance in predicting the presence of $T$. vivax infection in Nigerian goats. This was important given that these animals are reared extensively in the hot tropics, which in turn affects the presence of the tsetse fly vector $[5,6]$.

\section{Results}

\subsection{Prevalence of Trypanosoma vivax Infection Across Breeds, Sex and Geographical Locations in Nigerian Goats}

PCR using primers specific for T. vivax showed that 147 out of 205 goats were infected accounting for an average of $71.7 \%$ prevalence in the total goats investigated (Table 1). Among the breeds of goats examined, 15 out of $27(55.6 \%) \mathrm{SH}, 44$ out of $62 \mathrm{WAD}(71.0 \%)$ and 88 out of $116(75.9 \%)$ RS goats were found to be infected with the parasite. Between the sexes, the prevalence rates were 41 out of 60 bucks $(68.3 \%)$ and 106 out of 145 does $(73.1$ $\%)$. respectively. Geographically, the prevalence rates of subclinical T. vivax infections were 42 out of $59(71.2 \%)$ goats in Southwest, 42 out of $56(75.0 \%)$ goats in Northwest and 63 out of $90(70.0 \%)$ goats sampled in Northeast.

\subsection{Association of $T$. vivax Infection Status and Physiological Traits of Nigerian Goats.}

The effect of $T$. vivax infection status was significant ( $\mathrm{P}$ $<0.05)$ on the respiratory rate of Nigerian goats, but not significant $(\mathrm{P}>0.05)$ on the other physiological traits measured (Table 2). T. vivax infected goat breeds had reduced respiratory rate $(48.31 \pm 1.35$ breaths $/ \mathrm{min})$ compared to their non-infected counterparts $(53.69 \pm 2.4$ breaths/min).

\subsection{Association of T. vivax Infection on Serum Metabolites of Nigerian Goats}

T. vivax infection status only had significant effect $(\mathrm{P}<$

Table 1. Prevalence of $T$. vivax according to the breed, sex and geographical location of Nigerian goats.

\begin{tabular}{ccccc}
\hline \multirow{3}{*}{ Sex } & Description & $\begin{array}{c}\text { Number } \\
\text { Tested }\end{array}$ & $\begin{array}{c}\text { Number } \\
\text { Positive }\end{array}$ & $\begin{array}{c}\text { Prevalence } \\
\text { Rate (\%) }\end{array}$ \\
\hline Breed $^{\mathrm{x}}$ & WAD & 62 & 44 & 71.0 \\
& RS & 116 & 88 & 75.9 \\
& SH & 27 & 15 & 55.6 \\
& TOTAL & 205 & 147 & 71.7 \\
& Male & 60 & 41 & 68.3 \\
& Female & 145 & 106 & 73.1 \\
& South-West & 59 & 42 & 71.2 \\
& North-West & 56 & 42 & 75.0 \\
& North-East & 90 & 63 & 70.0 \\
\hline
\end{tabular}

$\mathrm{WAD}=$ West African Dwarf goats; RS=Red Sokoto goats; $\mathrm{SH}=$ Sahel goats. 
Table 2. Effect of $T$. vivax infection on the mean $( \pm \mathrm{SE})$ physiological traits of Nigerian goats.

\begin{tabular}{cccccc}
\hline T. vivax & Pulse rate (beats/min) & Respiratory rate (breaths/min) & Body temperature $\left({ }^{\circ} \mathrm{C}\right)$ & Rectal temperature $\left({ }^{\circ} \mathrm{C}\right)$ & Heat stress index \\
\hline Absence & $128.67 \pm 4.39^{\mathrm{a}}$ & $53.69 \pm 2.4^{\mathrm{a}}$ & $38.52 \pm 0.15^{\mathrm{a}}$ & $39.34 \pm 0.09^{\mathrm{a}}$ & $4.53 \pm 0.56^{\mathrm{a}}$ \\
Presence & $126.32 \pm 2.54^{\mathrm{a}}$ & $48.31 \pm 1.35^{\mathrm{b}}$ & $38.38 \pm 0.11^{\mathrm{a}}$ & $39.12 \pm 0.06^{\mathrm{a}}$ & $4.63 \pm 0.05^{\mathrm{a}}$ \\
\hline
\end{tabular}

${ }^{\mathrm{a} b} \mathrm{M}$ Means with the same superscript within the same row do not differ significantly $(\mathrm{P}>0.05)$.

Table 3. Effects of $T$. vivax infection status on the serum biochemical indices of Nigerian goats.

\begin{tabular}{|c|c|c|}
\hline Parameter & Non-infected & Infected \\
\hline Glucose (mg/dl) & $48.97 \pm 2.90^{\mathrm{a}}$ & $49.80 \pm 2.05^{\mathrm{a}}$ \\
\hline Total protein $(\mathrm{g} / \mathrm{L})$ & $70.83 \pm 2.37^{\mathrm{a}}$ & $66.78 \pm 1.67^{\mathrm{a}}$ \\
\hline Albumin $(g / L)$ & $42.31 \pm 1.41^{\mathrm{a}}$ & $41.58 \pm 0.91^{\mathrm{a}}$ \\
\hline Globulin $(\mathrm{g} / \mathrm{L})$ & $28.52 \pm 1.57^{\mathrm{a}}$ & $25.20 \pm 1.14^{\mathrm{a}}$ \\
\hline Urea (Mg/dl) & $46.12 \pm 2.16^{\mathrm{a}}$ & $48.02 \pm 1.59^{\mathrm{a}}$ \\
\hline Cholesterol (mg/dl) & $113.04 \pm 5.29^{\mathrm{a}}$ & $16.19 \pm 3.83^{\mathrm{a}}$ \\
\hline Creatinine (mg/dl) & $1.49 \pm 0.09^{\mathrm{b}}$ & $1.72 \pm 0.05^{\mathrm{a}}$ \\
\hline Chloride (mmol/L) & $123.56 \pm 6.02^{\mathrm{a}}$ & $131.74 \pm 4.55^{\mathrm{a}}$ \\
\hline Sodium (mmol/L) & $151.96 \pm 3.04^{\mathrm{a}}$ & $149.38 \pm 1.88^{\mathrm{a}}$ \\
\hline Potassium (mmol/L) & $10.00 \pm 0.68^{\mathrm{a}}$ & $9.28 \pm 0.27^{\mathrm{a}}$ \\
\hline Calcium (mmol/L) & $10.78 \pm 0.43^{\mathrm{a}}$ & $10.92 \pm 0.37^{\mathrm{a}}$ \\
\hline Magnessium $(\mathrm{mmol} / \mathrm{L})$ & $3.83 \pm 0.21^{\mathrm{a}}$ & $3.53 \pm 0.13^{\mathrm{a}}$ \\
\hline Bilirubin (mg/dl) & $2.27 \pm 0.16^{\mathrm{a}}$ & $2.19 \pm 0.11^{\mathrm{a}}$ \\
\hline Triglyceride (mg/dl) & $95.05 \pm 3.49^{\mathrm{a}}$ & $99.61 \pm 2.51^{\mathrm{a}}$ \\
\hline $\mathrm{HDL}(\mathrm{mg} / \mathrm{dl})$ & $18.35 \pm 0.81^{\mathrm{a}}$ & $18.18 \pm 0.64^{\mathrm{a}}$ \\
\hline LDL (mg/dl) & $78.63 \pm 4.73^{\mathrm{a}}$ & $82.32 \pm 3.87^{\mathrm{a}}$ \\
\hline Phosphorus (mg/dl) & $11.62 \pm 0.45^{\mathrm{a}}$ & $10.78 \pm 0.32^{\mathrm{a}}$ \\
\hline ALP (IU/L) & $240.87 \pm 13.92^{\mathrm{a}}$ & $232.22 \pm 7.36^{\mathrm{a}}$ \\
\hline SGOT (IU/L) & $172.87 \pm 16.46^{\mathrm{a}}$ & $160.12 \pm 9.06^{\mathrm{a}}$ \\
\hline SGPT (IU/L) & $86.68 \pm 3.97^{\mathrm{a}}$ & $87.28 \pm 2.73^{\mathrm{a}}$ \\
\hline
\end{tabular}

${ }^{a, b}$ Means with the same superscript within the same row do not differ significantly $(\mathrm{P}>0.05)$.

0.05) on the creatinine levels of Nigerian goats (Table 3).Infected goats had higher creatinine level (1.72 \pm 0.05 $\mathrm{mg} / \mathrm{dl})$ compared to their non-infected counterparts (1.49 $\pm 0.09 \mathrm{mg} / \mathrm{dl}$ ). The effect of $T$. vivax infection status was not significant $(\mathrm{P}>0.05)$ on other serum metabolites.

\subsection{Effect of Breed on Physiological Traits of Nigerian Goats}

Although the mean pulse rate and respiratory rate of WAD goats $(124.97 \pm 3.1$ beats $/ \mathrm{min}$ and $59.1 \pm 2.59$ breaths $/ \mathrm{min}$ ) were high statistically $(\mathrm{P}<0.05)$, this did not result in stressed condition $(\mathrm{P}>0.05)$ based on their lower heat stress index compared to the SH and RS goats, respectively (Table 4).

\subsection{Prediction of Subclinical Trypanosomiasis Using Physio-logical (Heat Tolerant) Traits}

Across breeds, the logistic regression revealed that respiratory rate was the trait of utmost importance $(\mathrm{P}<0.05)$ in predicting the presence of $T$. vivax infection in extensively reared Nigerian goats. Among breeds, the prediction models showed that respiratory rate was the utmost trait of importance $(\mathrm{P}<0.05)$ in predicting the presence of $T$. vivax infection in WAD and RS goats, respectively, while pulse rate and rectal temperature were more important $(\mathrm{P}<0.05)$ in estimating the presence of $T$. vivax infection in SH goats. The overall fitted model for Nigerian goats (irrespective of breeds) was T. vivax $=1.85-(0.02$ $\times$ respiratory rate), while $T$. vivax $=2.81-(0.03 \times$ respiratory rate $) ; T$. vivax $=2.67-(0.03 \times$ respiratory rate $)$; and $T$. vivax $=88.73+(0.03 \times$ pulse rate $)-(3.48 \times$ rectal temperature) were fitted for WAD, RS and SH goats, respectively.

\section{Discussion}

Animal trypanosomosis remains one of the most important constraints of animal production in African countries [19]. Molecular diagnosis using PCR assay has been found in this study to be an efficient and effective tool in the diagnosis of trypanosome infection, which is consistent with the findings of earlier workers on the use of this method for the detection of various livestock diseases [20-24]. The high prevalence rate of sub-clinical T. vivax infection was a further indication that Nigerian goats harbour this parasite and may act as a critical reservoir, similar to the findings of Ohaeri [25]. The relative frequency of infections with $T$. vivax in the present study was higher than the $25.0 \%$ reported for goats in Ethiopia [26] and for sheep (18.2\%) and goats (1.3\%), respectively in Kenya [27]. The unexpectedly higher incidence of T. vivax infection in RS goats found mostly in the northern parts of Nigeria (tsetse non-endemic zone), might be the result of low resistance to the parasite which could have been introduced through mechanical transmission. This was contrary to their WAD counterparts 
Table 4. Effect of breed on the mean physiological traits of extensively managed Nigerian goats.

\begin{tabular}{cccccc}
\hline Breed & Pulse rate $($ beats/min) & Respiratory rate $($ breaths $/$ min) & Body temperature $\left({ }^{\circ} \mathrm{C}\right)$ & Rectal temperature $\left({ }^{\circ} \mathrm{C}\right)$ & Heat stress index \\
\hline WAD & $124.97 \pm 3.1^{\mathrm{a}}$ & $59.1 \pm 2.59^{\mathrm{a}}$ & $38.84 \pm 0.18^{\mathrm{a}}$ & $39.25 \pm 0.1^{\mathrm{a}}$ & $4.4 \pm 0.05^{\mathrm{a}}$ \\
$\mathrm{RS}$ & $131.47 \pm 2.99^{\mathrm{a}}$ & $47.89 \pm 1.31^{\mathrm{b}}$ & $38.19 \pm 0.11^{\mathrm{a}}$ & $39.21 \pm 0.07^{\mathrm{a}}$ & $4.62 \pm 0.5^{\mathrm{a}}$ \\
$\mathrm{SH}$ & $112.33 \pm 7.46^{\mathrm{b}}$ & $36.89 \pm 1.87^{\mathrm{c}}$ & $38.41 \pm 0.14^{\mathrm{a}}$ & $38.94 \pm 0.12^{\mathrm{a}}$ & $4.74 \pm 0.09^{\mathrm{a}}$ \\
\hline
\end{tabular}

a,b,c Means with the same superscript within the same row do not differ significantly $(\mathrm{P}>0.05)$; WAD=West African Dwarf goats; RS = Red Sokoto goats; SH = Sahel goats.

that have adapted to the humid tropical conditions (tsetse endemic zone) of southern Nigeria [28]. Entomological surveillance would therefore be important to establish the correlation between the abundance period of cyclical and/or mechanical vectors (tsetse flies and haematophagous biting flies such as tabanids and stomoxys) and trypanosome infection [29]. According to Migchelsen et al. [30], a common problem in non-endemic regions is an initial misdiagnosis. The chronic nature, non-specific clinical signs and symptoms, and low parasitemia may result in the disease remaining undiagnosed and unrecognized for years. In addition, a more holistic picture of trypanosomosis requires a comprehensive understanding of the epidemiology of the disease, the roles of different trypanosome species, mixed infections, and different host species [31].

In mammals, respiration is directed at the elimination of $\mathrm{CO}_{2}$ from tissues of the body and evaporation of moisture from the respiratory tract helps to prevent hyperthermia under high ambient temperatures [32], which is a major adaptive feature of domestic livestock in the hot humid tropics of Sub-Saharan Africa. Respiratory rate was found to be significantly affected by pathogenic T. vivax. The reduced respiratory rates of infected goats indicate that the infected animals may be more stressed than non-infected animals. This suggests that pathogenic T. vivax infection is a stressor in goats, and the measurement of respiratory rate is an indication of the physiological alterations of stressed and infected animals $[33,34]$. This result is corroborated by earlier reports by Fajinmi, et al. [35] in cattle. Although there was a tendency towards higher heat stress in SH and RS goats found in the hotter, northern parts of the country, this was not significant because they are more adapted to the higher ambient temperatures of northern compared to southern Nigeria.

Measurement of biochemical parameters is an important and reliable way to assess the health status of animals, as changes in these parameters are indicators of pathophysiological responses under disease assaults such as trypanosomosis [36]. Only creatinine, a metabolic waste product formed in the muscle from creatinine phosphate was found to be significantly affected in this study. This effect was higher in infected than in noninfected animals. These were consistent with earlier re- ports of increased creatine levels in goats experimentally infected by Trypanosoma spp [37,38] but opposite to reports during experimental infection of T. brucei [39] and $T$. congolense [40] in goats. This seeming discrepancy may be explained by the different animal responses to different Trypanosoma species and the fact that many other variables were actively being manipulated under controlled conditions such as dietary energy and protein metabolism in these other studies compared to detection of subclinical levels of infection in extensively managed goats in this study.

The regression analyses indicate that respiratory rate, pulse rate and rectal temperature in goats could be used to predict existing subclinical T. vivax infection in extensively managed Nigerian goats. This result is similar to findings of earlier workers $[15,41,42]$ that rectal temperature, respiratory rate and body temperature can be used as good assessment of heat stress in goats because they are excellent indicators of physiological response and adaptability to extremes of weather and thermal environment. The constant exposure of these animals to thermal stress brings physiological parameters into play with respect to subclinical infections. These environmental factors have direct effects on the animals and on the ecology of tsetse fly vector of the disease. The prediction models obtained in this study are simple and economical, and could be applied in the field as a first step in the determination of the health status of the animals and the putative diagnosis of subclinical trypanosomosis pending the use of laboratory assays.

In conclusion, this study has established that subclinical infections of $T$. vivax infection can be assessed by PCR, and this may provide preemptive ability to address disease burden in Nigerian goats. Logistic regression analysis showed that respiratory rate was the heat tolerant trait of utmost importance in predicting the presence of $T$. vivax infection in extensively managed Nigerian goats. The use of PCR as a viable tool for large-scale epidemiological surveillance should be encouraged in diagnosing and identifying the prevalence of more deadly trypanosome species in Nigerian goats such as T. brucei, $T$. congolense kilifi, $T$. congolense savanna type, and $T$. congolense forest type in both endemic and non-endemic zones. The epidemiological data generated from preva- 
lence of T. vivax infection in Nigerian goats could aid policy formulation for disease control and animal management strategies. This will contribute to attenuating the rate of trypanosome infections in extensively managed goats in tropical regions where the disease is endemic.

\section{Acknowledgements}

Financial support for this study provided by the College of Agriculture and Life Sciences, Cornell University, Ithaca, USA is gratefully acknowledged. We are also grateful to the goat traders, small holders and research farms for permission to sample the animals. Approval by Prof. W. Ron Butler to MAA, AY, MIT as visiting graduate students to Cornell University is also gratefully acknowledged.

\section{REFERENCES}

[1] A. Mugisha, A. Mcleod, R. Percy and E. Kyewalabye, "Socio-Economic Factors Influencing Control of VectorBorne Diseases in the Pastoralist System of South Western Uganda," Tropical Animal Health and Production, Vol. 40, No. 1, 2008, pp. 287-297.

doi:10.1007/s11250-011-9943-9

[2] T. T. Desta, W. Ayalew and P. B. Hedge, "Farmers' Perceptions on Trypanosomosis and Trypanotolerance Character of the Taurine Sheko," Tropical Animal Health and Production, Vol. 44, No. 3, 2012, pp. 609-616. doi:10.1007/s11250-011-9943-9

[3] D. Tesfaye, N. Speybroeck, R. De Deken and E. Thys, "Economic Burden of Bovine Trypanosomosis in Three Villages of Metekel Zone, Northwest Ethiopia," Tropical Animal Health and Production, Vol. 44, No. 4, 2011, pp. 873-879. doi:10.1007/s11250-011-9981-3

[4] P. R. Torgerson and C. N. L. Macpherson, "The Socioeconomic Burden of Parasitic Zoonoses: Global Trends," Veterinary Parasitology, Vol. 182, No. 1, 2011, pp. 79-95. doi:10.1016/j.vetpar.2011.07.017

[5] P. Van den Bossche and R. De Deken, "Seasonal Variations in the Distribution and Abundance of the Tsetse Fly, Glossina morsitans in Eastern Zambia," Medical and Veterinary Entomology, Vol. 16, No. 1, 2002, pp. 170-176. doi:10.1046/j.1365-2915.2002.00360.x

[6] P. J. Hotez and A. Kamath, "Neglected Tropical Diseases in Sub-Saharan Africa: Review of their Prevalence, Distribution and Disease Burden," PLoS Neglected Tropical Diseases, Vol. 3, No. 8, 2009, p. e412. doi:10.1371/journal.pntd.0000412

[7] M. C. Ezeani, H. Okoro, V. O. Anosa, C. C. Onyenekwe, S. C. Meludu, C. E. Dioka and C. C. Azikiwe, "Immunodiagnosis of Bovine Trypanosomosis in Anambra and Imo States, Nigeria, Using Enzymes Linked Immunosorbent Assay: Zoonotic Implication to Human Health," Journal of Vector Borne Diseases, Vol. 45, No. 1, 2008, pp. 292-300.

[8] I. Malele, L. Craske, C. Knight, V. Ferris, Z. K. Njiru, P. Hamilton, L. Stella, M. Lehane and W. C. Gibson, "The
Use of Specific and Generic Primers to Identify Trypanosome Infections of Wild Tsetse Flies in Tanzania by PCR," Infection Genetics and Evolution, Vol. 3, No. 1, 2003, pp. 271-279. doi:10.1016/S1567-1348(03)00090-X

[9] G. Z. Lin, F. Y. Zheng, J. Z. Zhou, X. W. Gong, G. H. Wang, X. H. Cao and C. Q. Qiu, "Loop-Mediated Isothermal Amplification Assay Targeting the OMP25 Gene for Rapid Detection of Brucella Spp," Molecular and Cellular Probes, Vol. 23, No. 1, 2011, pp. 126-129. doi:10.1016/j.mcp.2011.01.001

[10] S. M. Thumbi, F. A. McOdimba, R. O. Mosi and J. O. Junga, "Comparative Evaluation of Three PCR Base Diagnostic Assays for the Detection of Pathogenic Trypanosomes in Cattle Blood," Parasites and Vectors, Vol. 1, No. 1, 2008, p. 46. doi:10.1186/1756-3305-1-46

[11] Z. K. Njiru, C. C. Constantine, S. Guya, J. Crowther, J. M. Kiragu, R. C. Thompson and A. M. Dávila, "The Use of ITS1 rDNA PCR in Detecting Pathogenic African Trypanosomes," Parasitology Research, Vol. 95, No. 2005, pp. 186-192.

[12] D. K. Masiga, A. J. Smyth, P. Hayes, T. J. Bromidge and W. C. Gibson, "Sensitive Detection of Trypanosomes in Tsetse Flies by DNA Amplification," International Journal for Parasitology, Vol. 22, No. 1, 1992, pp. 909-918. doi:10.1016/0020-7519(92)90047-O

[13] R. A. Masake, P. A. Majiwa, S. K. Moloo, J. M. Makau, J. T. Njuguna, M. Maina, J. Kabata, O. K. ole-MoiYoi and V. M. Nantulya, "Sensitive and Specific Detection of Trypanosoma vivax Using the Polymerase Chain Reaction," Experimental Parasitology, Vol. 85, No. 2, 1997, pp. 193-205. doi:10.1006/expr.1996.4124

[14] Z. K. Njiru, J. O. Ouma, R. Bateta, S. E. Njeru, K. Ndungu, P. K. Gitonga, S. Guya and R. Traub, "Loop-Mediated Isothermal Amplification Test for Trypanosoma vivax Based on Satellite Repeat DNA," Veterinary Parasitology, Vol. 180, No. 1, 2011, pp. 358-362. doi:10.1016/j.vetpar.2011.03.021

[15] B. S. Oladimeji, O. A. Osinowo, J. P. Alawa and J. O. Hambolu, "Estimation of Average Values for Pulse Rate, Respiratory Rate and Rectal Temperature and Development of Heat Stress Index for Adult Yankassa Sheep," Bulletin of Animal Health and Production, Vol. 44, No. 1, 1996, pp. 105-107.

[16] N. C. Jain, "Schalman's Veterinary Haematology," 4th Edition, Lea and Babings, Philadelphia, 1986, pp. 208224.

[17] "SAS Users Guide: Statistics Ver. 9.1," Statistical Analysis System Inc., Cary, 2009.

[18] D. W. Hosmer and S. Lemeshow, "Applied Survival Analysis: Regression Modeling of Time to Event Data," 2nd Edition, John Wiley and Sons Inc., New York, 2008.

[19] S. Mekuria and F. Gadissa, "Survey on Bovine Trypanosomosis and Its Vector in Metekel and Awi Zones of Northwest Ethiopia," Acta Tropica, Vol. 117, No. 1, 2011, pp. 146-151. doi:10.1016/j.actatropica.2010.11.009

[20] A. Cox, A. Tilley, F. McOdimba, J. Fyfe, M. Eisler, G. Hide and S. Welburn, "A PCR Based Assay for Detection and Differentiation of African Trypanosome Species in Blood," Experimental Parasitology, Vol. 111, No. 1, 2005, 
pp. 24-29. doi:10.1016/j.exppara.2005.03.014

[21] J. L. Gonzales, A. Loza and E. Chacon, "Sensitivity of Different Trypanosoma vivax Specific Primers for the Diagnosis of Livestock Trypanosomosis Using Different DNA Extraction Methods," Veterinary Parasitology, Vol. 136, No. 1, 2006, pp. 119-126.

doi:10.1016/j.vetpar.2005.10.024

[22] F. J. Li, B. Robin, R. B. Gasser, D. H. Lai, F. Claes, X. Q. Zhu and Z. R. Lun, "PCR Approach for the Detection of Trypanosoma brucei and T. equiperdum and Their Differentiation from T. evansi Based on Maxicircle Kinetoplast DNA," Molecular Cellular Probe, Vol. 21, No. 1, 2007, pp. 1-7. doi:10.1016/j.mcp.2006.03.009

[23] G. J. N. Galiza, H. A. Garcia, A. C. O. Assis, D. M. Oliveira, L. A. Pimentel, A. F. M. Dantas, S. V. D. Simoes, M. M. G. Teixeira and F. Riet-Correa, "High Mortality and Lesions of the Central Nervous System in Trypanosomosis by Trypanosoma vivax in Brazilian Hair Sheep," Veterinary Parasitology, Vol. 182, No. 1, 2011, pp. 359-363. doi:10.1016/j.vetpar.2011.05.016

[24] M. T. Tejedor-Junco, M. Gonzalez, N. F. Rodriguez, J. A. Corbera and C. Gutierrez, "Comparison Between MicroHematocrit Centrifugation Technique and Polymerase Chain Reaction (PCR) to Detect Trypanosoma evansi in Experimentally Inoculated Goats," Small Ruminant Research, Vol. 96, No. 2011, 2011, pp. 70-72.

[25] C. C. Ohaeri, "Prevalence of Trypanosomiasis in Ruminants in Parts of Abia State, Nigeria," Journal of Animal and Veterinary Advances, Vol. 9, No. 18, 2010, pp. 24222426.

[26] H. Dinka and G. Abebe, "Small Ruminants Trypanosomosis in the Southwest of Ethiopia," Small Ruminant Research, Vol. 57, No. 1, 2005, pp. 239-243. doi:10.1016/j.smallrumres.2004.07.008

[27] D. K. Masiga, G. Okech, P. Irungu, J. Ouma, S. Wekesa, B. Ouma, S. O. Guya and J. M. Ndung'u, "Growth and Mortality in Sheep and Goats under High Tsetse Challenge in Kenya," Tropical Animal Health and Production, Vol. 34, No. 1, 2002, pp. 489-501. doi:10.1023/A:1021241220575

[28] J. O. Daramola and A. A. Adeloye, "Physiological Adaptation to the Humid Tropics with Special Reference to the West African Dwarf (WAD) Goat," Tropical Animal Health and Production, Vol. 41, No. 1, 2009, pp. 10051016. doi:10.1007/s11250-008-9267-6

[29] G. K. Dayo, Z. Bengaly, S. Messad, B. Bucheton, I. Sidibe, B. Cene, G. Cuny and S. Thevenon, "Prevalence and Incidence of Bovine Trypanosomosis in an AgroPastoral Area of Southwestern Burkina Faso," Research in Veterinary Science, Vol. 88, No. 1, 2010, pp. 470-477. doi:10.1016/j.rvsc.2009.10.010

[30] S. J. Migchelsen, P. Buscher, A. I. M. Hoepelman, H. D. F. H. Schallig and E. R. Adams, "Human African Trypanosomiasis: A Review of Non-Endemic Cases in the Past 20 Years," International Journal of Infectious Diseases, Vol. 15, No. 8, 2011, pp. 517-524. doi:10.1016/j.ijid.2011.03.018

[31] G. L. Pinchbeck, L. J. Morrison, A. Tait, J. Langford, L. Meehan, S. Jallow, A. Jallow and R. M. Christley, "Try- panosomosis in the Gambia: Prevalence in Working Horses and Donkeys Detected by Whole Genome Amplification and PCR, and Evidence for Interactions between Trypanosome Species," BMC Veterinary Research, Vol. 4, 2008, p. 7.

[32] I. F. M. Marai, A. A. El-Darawany, A. Fadiel and M. A. M. Abdel-Hafez, "Physiological Traits as Affected by Heat Stress in Sheep-A Review," Small Ruminant Research, Vol. 71, No. 1, 2007, pp. 1-12. doi:10.1016/j.smallrumres.2006.10.003

[33] E. H. von Borell, "The Biology of Stress and Its Application to Livestock Housing and Transportation Assessment," Journal of Animal Science, Vol. 79, No. 2001, 2001, pp. 260-267.

[34] S. Sadeghian, M. R. M. Dezfouli, G. A. Kojouri, T. T. Bazargani and A. Tavasoli, "Pasteurella multocida Pneumonic Infection in Goat: Hematological, Biochemical, Clinical and Pathological Studies," Small Ruminant Research, Vol. 100, No. 1, 2011, pp. 189-194. doi:10.1016/j.smallrumres.2011.07.006

[35] A. O. Fajinmi, J. N. Abenga, F. A. G. Lawani, J. C. A. Ukah, E. C. D. Ikemereh and P. U. Nwabuko, "An Outbreak and Observations on Trypanosomiasis in Friesian Cattle at Sabon-Birni, Kaduna State of Nigeria," African Journal of Clinical and Experimental Microbiology, Vol. 7, No. 1, 2006, pp. 28-34.

[36] C. C. Ohaeri and M. C. Eluwa, “Abnormal Biochemical and Haematological Indices in Trypanosomiasis as a Threat to Herd Production," Veterinary Parasitology, Vol. 177, No. 1, 2011, pp. 199-202. doi:10.1016/j.vetpar.2011.02.002

[37] M. W. Verstegen, D., Zwart, W. van der, B. O. Hel Brouwer and T, Wensing, "Effect of Trypanosoma vivax Infection on Energy and Nitrogen Metabolism of West African Dwarf Goats," Journal of Animal Science, Vol. 69, No. 4, 1991, pp. 1667-1677.

[38] A. O. Ogunsanmi, S. O. Akpavie and V. O. Anosa, "Serum Biochemical Changes in West African Dwarf Sheep Experimentally Infected With Trypanosoma brucei," Revue D'élevage et de Médecine Vétérinaire des Pays Tropicaux, Vol. 47, No. 2, 1994, pp. 195-200.

[39] I. O. Igbokwe and A. Mohammed, "Some Plasma Biochemical Changes in Experimental Trypanosoma brucei Infection of Sokoto Red Goats," Revue D'élevage et de Médecine Vétérinaire des Pays Tropicaux, Vol. 45, No. 3-4, 1992, pp. 287-90.

[40] S. Osaer, O. O. Akinbamijo and B. Goossens, "Some Biochemical Changes Following Trypanosoma congolense Infection in Djallonké Ewe Lambs and Breeding Ewes Fed on Two Levels of Nutrition," Acta Tropica, Vol. 75, No. 2, 2000, pp. 229-241. doi:10.1016/S0001-706X(00)00060-7

[41] J. W. West, "Nutritional Strategies for Managing the Heat Stress in Dairy Cow," Animal Science Journal, Vol. 77, No. 1, 1999, pp. 21-35.

[42] I. S. Butswat, S. T. Mbap and G. A. Ayibantoye, "Heat Tolerance of Sheep in Bauchi Nigeria," Tropical Agriculture (Trinidad), Vol. 77, No. 1, 2000, pp. 265-268. 